\title{
Consilient knowledge in fisheries: a case study of three species of wolffish (Anarhichadidae) listed under the Canadian Species at Risk Act
}

\author{
Jennifer Dawe $^{1}$ and David Schneider ${ }^{1}$
}

\begin{abstract}
Three species of wolffish have been listed under Canada's Species at Risk Act with consequences for commercial fisheries. Because harvester based local ecological knowledge (LEK) and science knowledge differ in goals, spatial and temporal scale, and mode of generalization, the current system struggles with including LEK along with traditional assessments in species at risk (SARA) processes. The differences in LEK and science led us to consider the concept of consilience in the sense of strengthened inductive knowledge via convergence or concordance of evidence from disparate sources. We used three criteria when considering consilience: a general concurrence of data, presence of unexplained inconsistencies, and a degree of complementarity between two disparate sources. Using wolffish in the northern Gulf of St. Lawrence we examined the feasibility of applying these criteria to two disparate sources of information: scientific stock assessments and data from structured fish harvester local ecological knowledge (LEK) interviews. We found that for wolffish there was consistency in observed trends and locations of high wolffish catch rates from both harvester LEK interviews and fishery-independent survey data. There was inconsistency between observed variability in catch sizes in harvester interviews and stock assessment maps. The science and LEK evidence were complementary in that observations took place at different spatial and temporal scales. They were complementary in that LEK was inshore, compared to science data from offshore. The explicit criteria we developed permit use of fishers' knowledge that, in the past, has often been discounted to zero, often thereby reducing trust by harvesters in the results of species at risk assessments. The concept of consilience shifts the focus from controversy to dialogue in the use of evidence and, so, is important in rebuilding marine fishing communities.
\end{abstract}

Key Words: bycatch; fishery surveys; local ecological knowledge; species at risk; wolffish

\section{INTRODUCTION}

In the last decade there has been an increased focus on assessing the risk status of species on local, national, and global scales. Many countries, including Canada and the United States, as well as the European Union, have legislation in place to not only assess species, but also, in many cases, to protect those species identified as at risk of extirpation or extinction. Recent research has shown that, of the vertebrates listed, many fish stocks have been fished to the brink of commercial extinction; an even greater number of noncommercial species are disappearing from the world because of elimination of habitat and as bycatch in large fisheries (Dulvy et al. 2005).

Decisions on species assessment for fishes are primarily based on fisheries science, but for marine species there is a lack of scientific data. In Canada, with the introduction of the Species at Risk Act (SARA, www.sararegistry.gc.ca) in 2003, there has been a need to increase information on species' biology and abundance. SARA also has a mandate for the study of social and economic consequences that would stem from a listing. This has led to, among other considerations, consultation with stakeholders and the general public (Bourdages and Labelle 2003). For marine species, this includes consultations with fish harvesters and a potential examination of both available science and local ecological knowledge (LEK; SARA 2011). It is generally agreed that these considerations should be examined; however, as of yet there is no mechanism in place to support systematic, ongoing collection of LEK (Sáenz-Arroyo et al. 2005).

Although there is no universally accepted definition of LEK, Berkes et al. (2000) see it as having both empirical and conceptual aspects, being cumulative and dynamic over generations and changing in response to socioeconomic, technological, and other factors. In the case of fish harvesters' LEK, it includes not only fish species, but also information on behavior, annual cycles, winds, tides, and reference to species abundance and distribution, as well as fishing activity at spatial and temporal scales that may be different from those currently used by fisheries science (Neis et al. 1999a, Vodden et al. 2005). Most LEK tends to be spatially restricted to grounds fished, but can include information from fishers elsewhere and insights from science presented in meetings or in the media. In Newfoundland and Labrador, LEK is substantial because of a strong cultural and historical attachment to the area and the fishing industry.

LEK has only recently begun to be applied in fisheries management in some parts of the world, primarily because of dwindling stocks (Butler et al. 2012, Thornton and Maciejewski Scheer 2012, Van Holt 2012). It has differing levels of detail depending on the experience of the harvester (Espinoza-Tenorio et al. 2013). It differs from fishery-independent survey data on both temporal and spatial scales; fishery-independent survey data are usually taken at larger scales with a limited number of samples at fixed and very constrained times of the year, whereas LEK works on a smaller spatial scale from a far larger observational base over wider time frames. In Newfoundland, fishery surveys tend to be in deeper, often offshore waters, whereas LEK tends to be based on fishing in shallower, coastal areas. Fisheries science is designed to permit generalization from a necessarily limited number of samples to the larger area under investigation. LEK is place-specific (Murray et al. 2008) and so cannot be generalized to larger areas based on known sampling probability. Generalization rests instead on consistency of locally drawn information over many areas and fishers (Neis et al 1999b). 
Several marine fish species have been brought forward to be listed as species at risk; however, few have made it as far as legal protection. Three species of wolffish found along the coast of Newfoundland and Labrador have the distinction of being the only fully marine Atlantic Canadian fish to be listed under the SARA in Canada. Atlantic wolffish (Anarhichas lupus) were listed as "Special Concern" in 2000 and the spotted and northern wolffish (A. minor and $A$. denticulatus) were listed as "Threatened" in 2001 (Dawe and Neis 2012). These three species of wolffish have different habitat requirements in their shared ranges. A. lupus are less associated with the bottom, feeding on greater percentages of pelagic fish and lower percentages of benthic invertebrates than the other two species, and have the greatest range of depths, from 38 to $1500 \mathrm{~m}$ (Kulka et al. 2004). A. minor are the most southerly distributed species, found near shore to $900 \mathrm{~m}$ with concentrations at 150 to $350 \mathrm{~m}$ (Kulka et al. 2007). A. denticulatus have the most restricted distribution, and reside in waters between 56 and $1000 \mathrm{~m}$ with concentrations between 200 and $750 \mathrm{~m}$ (Kulka et al. 2007).

Wolffish have relatively low productivity based on growth, fecundity, and age characteristics, leaving them susceptible to rapid overexploitation (Musick 1999). There is no directed fishery for wolffish in Atlantic Canada; they are mainly caught as bycatch in many Atlantic commercial groundfish fisheries. The listing decision for these nontargeted species was based on results from an analysis of Fisheries and Oceans Canada (DFO) research vessel data showing that numbers of these large, slow-growing fish had declined by over $90 \%$ for all three species between 1983 and 1994 (Kulka et al. 2007), based on limited scientific data from a relatively short time series of offshore scientific trawl survey data.

Because LEK and science knowledge differ in goals, spatial and temporal scale, and mode of generalization, the current system struggles with including LEK along with traditional assessments in SARA processes (Usher 2000, Sáenz-Arroyo et al. 2005). The differences in LEK and science led us to consider the concept of consilience (Whewell 1840) in the sense of strengthened inductive knowledge via convergence or concordance of evidence from disparate sources. More specifically, we used three criteria when considering consilience: a general concurrence of data, presence of unexplained inconsistencies, and a degree of complementarity between two disparate sources, in this case LEK and science knowledge. Explicit treatment of both concurrence and inconsistency within the concept of consilience focuses on better knowledge. We examined the feasibility of applying these criteria for consilience by assembling two disparate sources of information: (1) LEK information on wolffish biology, abundance, and biogeography in a portion of the northern Gulf of St. Lawrence; and (2) results from fishery-independent survey data. The latter included data from a Sentinel mobile fishery, conducted in the northern Gulf between the Strait of Belle Isle and Burgeo on Newfoundland's south coast from 1999 to 2008, and research vessel survey data for the years 1970 to 1994 assembled through the East Coast of North America Strategic Assessment Project (ECNASAP). These criteria, if feasible, provide a basis for conjoint use of science and LEK to strengthen knowledge of species at risk through consilience and, thus, improve the assessment and monitoring of these species.

\section{METHODS}

\section{Harvester interviews}

Twenty-one local fish harvesters, chosen because of their experience as recognized by the fisheries union and colleagues, participated in face-to-face, semistructured LEK interviews. These interviews were completed in communities along the west coast of Newfoundland between Rose Blanche and St. Paul's (Fig. $1)$.

Fig. 1. Map of the study area, which includes Northwest Atlantic Fisheries Organization divisions 3Pn4R.

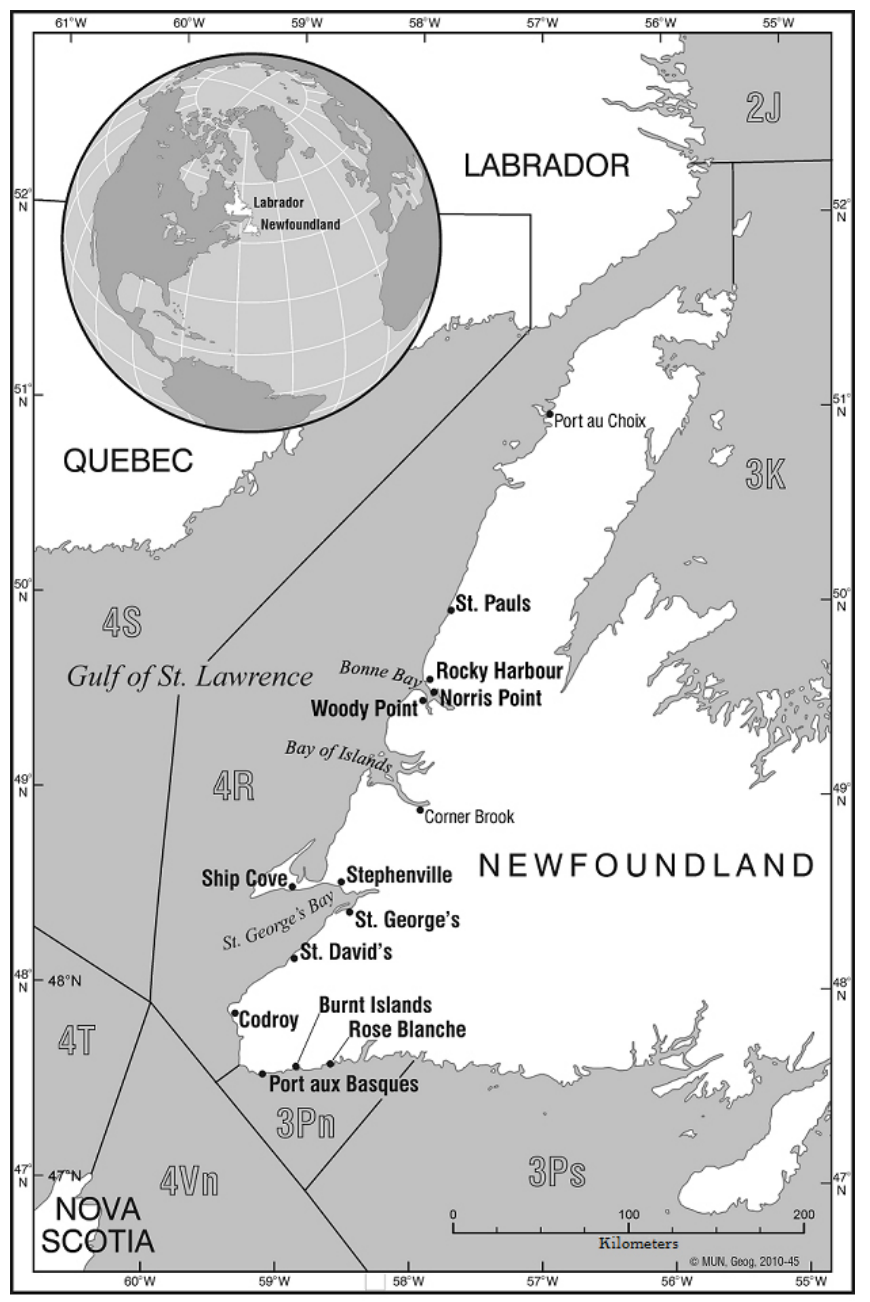

During the interviews, harvesters provided demographic information, e.g., fishing career length, community, port, and traditional fishing grounds; fishing history, e.g., species targeted, gear specifications, trends in catches, and fishing grounds; and their knowledge of wolffish on their fishing grounds, e.g., distinguishing features, common species seen, relative numbers, biology and abundance, and distribution on the grounds. Fishing grounds were recorded either on paper or on electronic versions of the Canadian Hydrographic Service (CHS) nautical charts. Frequency of response was analyzed and composite charts 
containing data from all harvester interviews were created by combining mapped fishing grounds associated with each major area studied. Fishing grounds were denoted by polygons with numbers linking them with the corresponding fishery and wolffish information from the transcript.

All interview recordings were transcribed and analysed. Excerpts from the transcript were grouped into categories based on content: demographics, fishing history, listing opinions, and conservation. The information in each of these categories was then coded into a series of finer categories and quotes were inserted into the relevant fields. In the fishing history section of the database, using ArcGIS ${ }^{\circledR}$, numbers were linked to corresponding points and polygons on the digital charts were inserted, along with the corresponding fishery and wolffish information from the transcript.

\section{Fishery-independent survey data}

\section{ECNASAP data}

The East Coast of North America Strategic Assessment Project (ECNASAP), initiated in 1991, is a collaborative effort across U. S. and Canadian agencies designed to make maximum use of existing data, information, and knowledge by developing comprehensive information and map products. The Groundfish database contains merged data sets of standard research assessment trawl surveys collected between 1970 and 1994 from Cape Hatteras, North Carolina, USA to Cape Chidley, Labrador, Canada (Brown et al. 1996). Corrections were made to handle taxonomic errors and inconsistencies in species coding systems among the surveys. The overall dataset contains 55,043 tows with 26,286,369 individuals from 412 species, including some aggregate groups. Data for $3 \mathrm{Pn}$ and $4 \mathrm{R}$ contained in the ECNASAP database were from DFO research vessel survey results generated from randomly generated, depth-stratified fishing stations and bottom trawl gear (additional information can be found in Brown et al. 1996 and Dawe 2010). Catch per unit effort (CPUE) yearly averages were regressed against year for all three species of wolffish in 4R from 1970 to 1994.

\section{Mobile Sentinel fishery}

The Groundfish Sentinel Program, initiated in 1994, is a series of research activities that use government funds and proceeds from research catches to engage commercial groundfish fishers over sections of the Atlantic Coast in structured fishing for scientific purposes (Fréchet et al. 2009). Data were collected from fishing stations that were randomly generated, following a depth based stratification (the variable most likely to influence groundfish distribution) for depths ranging between 40 and 400 m outside of bays and fjords. Surveys took place during the beginning week of July and, from 1995 to 2002, in October. Surveying was done using shrimp trawl gear equipped with rock hoppers, calibrated using a catch control system and restrictor cables to reduce variability in wing spread (16.5 m; Fréchet et al. 2009). Five vessels performed approximately $300,15-30$ minute tows at 2.5 knots at predetermined depths and locations during each survey. The data for all five vessels were combined during analysis because of the calibration.

Mobile Sentinel survey data resulting from this program were obtained for 3Pn and 4R for the years 1999 to 2008. Composite maps of relative abundance and distribution for all three species in $4 \mathrm{R}$ and $3 \mathrm{Pn}$ were created using ArcGIS ${ }^{\circ}$. Expanding bubble plots were created, dividing the data by year and species. Adult to juvenile ratios in both interview data and stock assessment surveys were calculated for $A$. lupus. Length at maturity in $3 \mathrm{Pn}$ and $4 \mathrm{R}$ was not known but is assumed here to be $55 \mathrm{~cm}$ (McRuer et al. 2000).

\section{RESULTS}

\section{Harvester interviews}

The 21 harvesters who participated in the wolffish interviews had fishing careers that ranged between 13 and 39 years (average career length was 28 years). They participated in, on average, four fisheries and were generally skippers of their own boats. Interviews ran on average 43 minutes, but the length of the interview depended on experience with wolfish, catch size, and the extent of the discussion evoked by the questions. Gear type used by harvesters included longline ( $\mathrm{J}$ and circle hooks), lobster pots, gillnets, Danish seines, and crab pots. Depths fished ranged from $2 \mathrm{~m}$ (with lobster pots) to $1200 \mathrm{~m}$ (with crab pots and longlines). Months on the water ranged from April to November, with a winter cod fishery in the past and some in 3Pn still fishing cod in the winter (December to March). Additional information on fisher demography can be found in Dawe (2010).

When asked to identify wolffish species caught as bycatch, all 21 harvesters reported catches containing $A$. lupus and $A$. minor in Atlantic cod, lobster, lumpfish, halibut, winter flounder, grey sole, and snow crab fisheries during the past and present summer fishing seasons (April to September) and the past winter seasons (November to January-February). Sixteen reported catches of $A$. denticulatus from cod, halibut, and snow crab fisheries during the past and present summer fishing season and past winter season.

Figures 2 through 4 compare composite charts created from information collected from all harvesters (polygon graph) and fishery-independent survey data (bubble plot). Each polygon represents a collection of fishing grounds where wolffish were reported to have been caught and do not indicate presence and absence. Areas outside polygons do not represent areas without wolffish; these are areas outside fishing grounds or areas where fishing gear did not catch wolfish.

Harvester reports of $A$. lupus were most common in shallow waters $(2-40 \mathrm{~m})$ in all areas (Fig. 2). Harvesters who fished from Bay of Islands to St. Paul's caught, on average, less wolffish than those fishing further south in similar fisheries between Rose Blanche and Bay St. George. These larger and more predictable catch sizes, increasing in the direction of Port aux Basques, suggest a southward trend in population over the study area. A. minor, though often reported in the same depths as $A$. lupus, were caught more commonly in the deeper $(40-150 \mathrm{~m})$ part of the range (Fig. 3). A. denticulatus appeared to be associated with deeper waters because they were not often caught in inshore fisheries. Harvesters reported catching them in depths ranging from $100-350 \mathrm{~m}$ (Fig. 4).

\section{Catch rates}

Harvesters were asked to describe their catch rates for each species on their different fishing grounds and in different fisheries. These catch rates varied greatly among areas and between wolffish species. Both past (beginning of career) and present (current 
Fig. 2. A comparison of fishery-independent data (bubble plot) and local ecological knowledge interview data (polygons) for Anarhichas lupus.

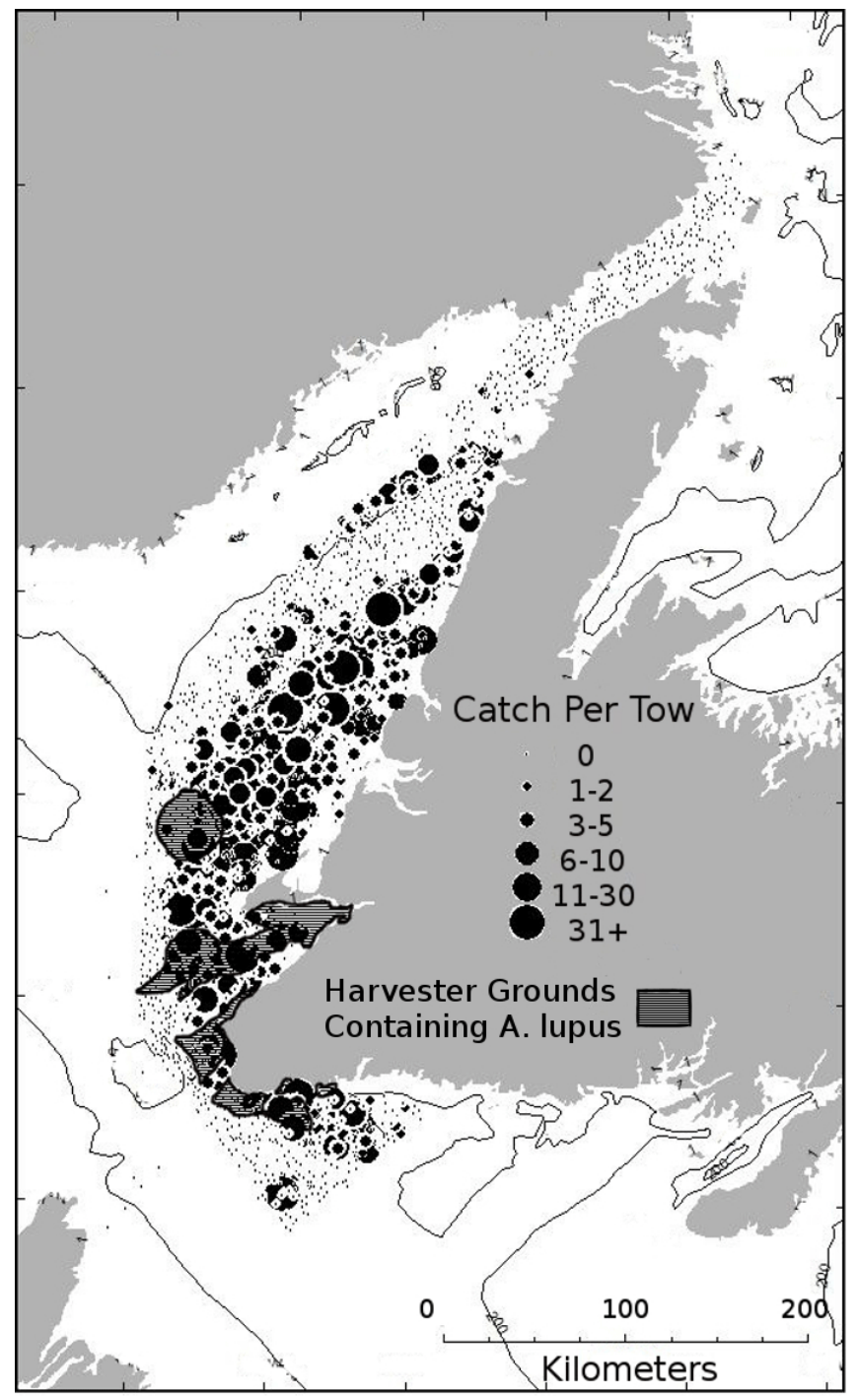

season) catch rates were divided into low and high rates; low catch rates, described by 12 harvesters, represented fewer than 10 wolffish caught during a week or a season. High catch rates, described by eight harvesters, represented over 10 wolffish caught during a week. High catches ranged upward to 80 wolffish, of all species, a day. Harvesters did not report any consistent way of avoiding large catches of wolffish, but all were aware of the best practices for live release because of educational materials from DFO.

Current catch rates of all three species of wolffish reported by harvesters were compared with catch rates from the beginning of their careers to determine relative trends. Harvesters reported either no change $(\mathrm{n}=7)$ or increased catch rates $(\mathrm{n}=12)$ of $A$. lupus over their careers. Four harvesters from Bay of Islands to
Fig. 3. A comparison of fishery-independent data (bubble plot) and local ecological knowledge interview data (polygons) for Anarhichas minor.

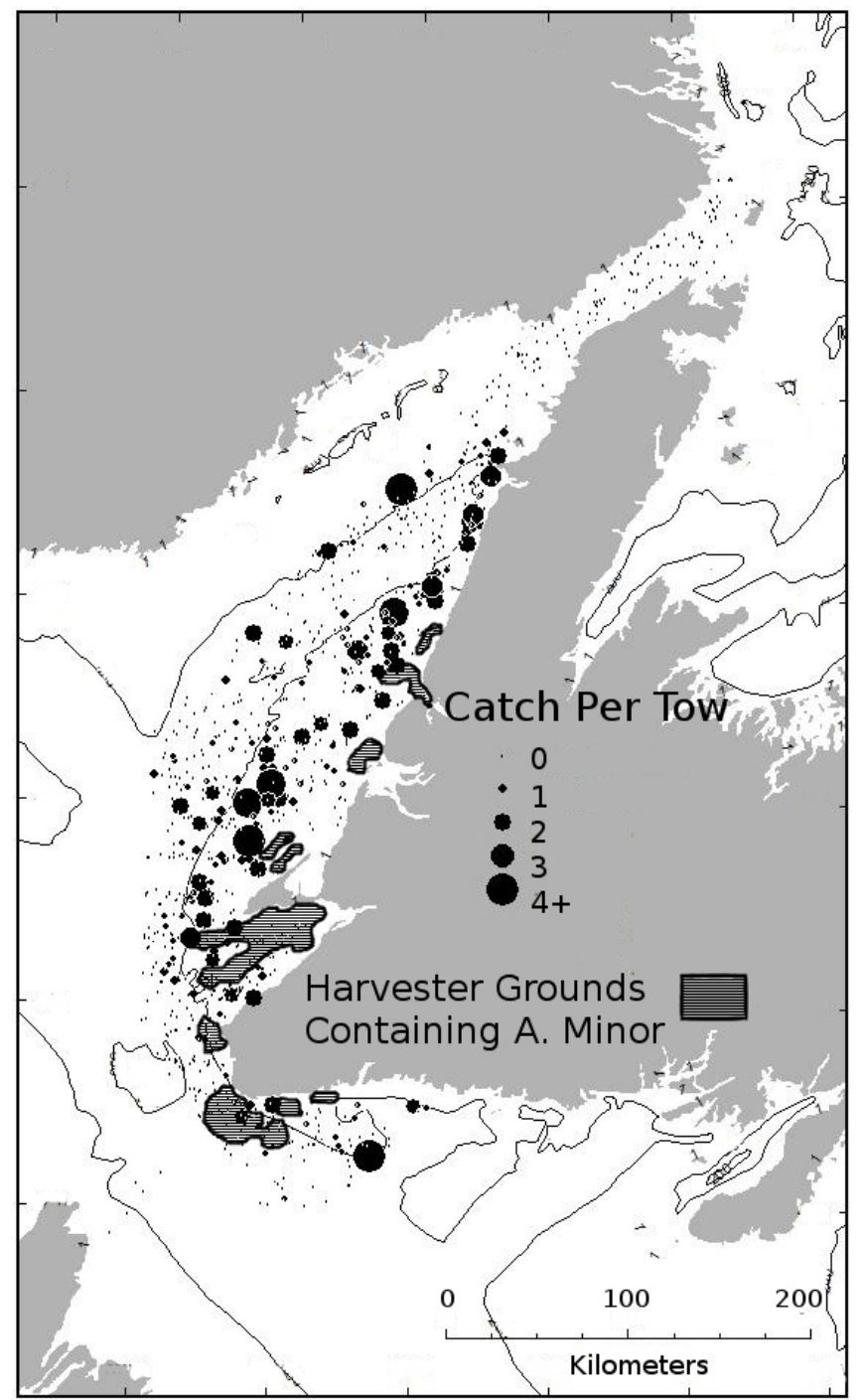

St. Paul's reported reduced numbers of $A$. denticulatus and $A$. minor in their catches from the beginning of their careers (1970s) to the current season.

\section{Sizes}

When asked about the sizes of the wolffish intercepted by their gear, harvesters consistently reported large wolffish $(0.60-2 \mathrm{~m})$ in the inshore fisheries. A. lupus was the smallest of the three species observed in their gear; harvesters assumed this was because most were caught in lobster pots, which exclude large wolffish while smaller ones can escape.

Harvesters reported $A$. lupus sizes ranging from $0.6-1.2 \mathrm{~m}$ and from $2-5 \mathrm{~kg}(\mathrm{n}=12)$. A. minor were reported to be much longer and larger than $A$. lupus; the few $A$. minor caught in lobster pots 
Fig. 4. A comparison of fishery-independent data (bubble plot) and local ecological knowledge interview data (polygons) for Anarhichas denticulatus.

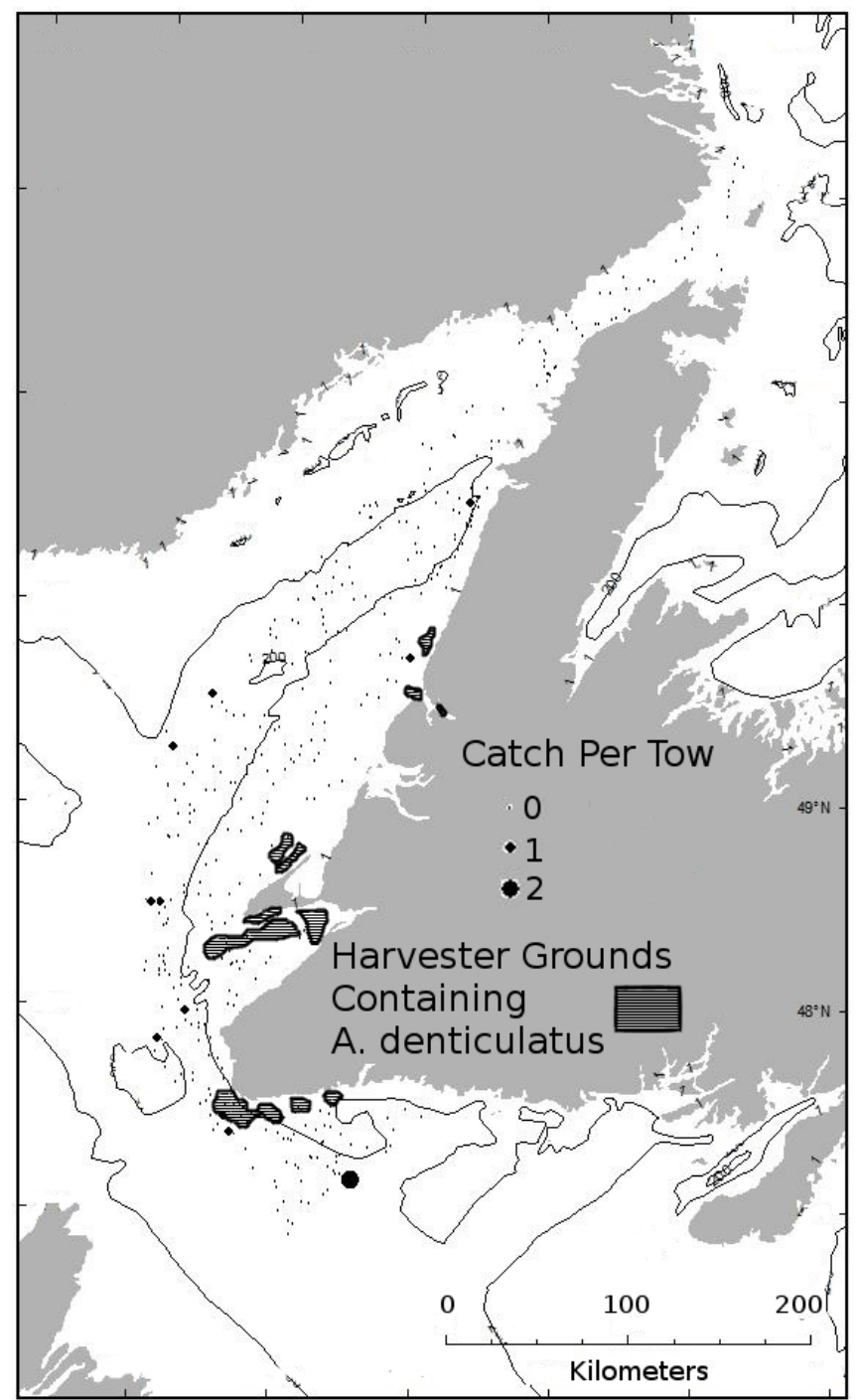

were reported to be 3 - 4 times the size of $A$. lupus $(\mathrm{n}=4)$. Based on the interview data, the average sizes of $A$. minor ranged from $1-2 \mathrm{~m}$ and $13-27 \mathrm{~kg}$. A . denticulatus were also reported to be large with sizes ranging from $11-23 \mathrm{~kg}$. No lengths were given for this species. Reported sizes were assumed to be from recent years by the interviewer. Eleven harvesters reported that all three species were larger since the listing had occurred and that only small numbers of $A$. lupus could be kept.

Fishery-independent survey data

Four sources of fishery-independent data were available, two from the waters surrounding Newfoundland and two from the Gulf of St. Lawrence, on the west coast of Newfoundland (Table 1).
Fig. 5. Catch per unit effort (CUPE) from the East Coast of North America Strategic Assessment Project data for Northwest Atlantic Fisheries Organization division 4R from 1970 to 1994 for (a) Anarhichas lupus, (b) A. minor, and (c) A. denticulatus.
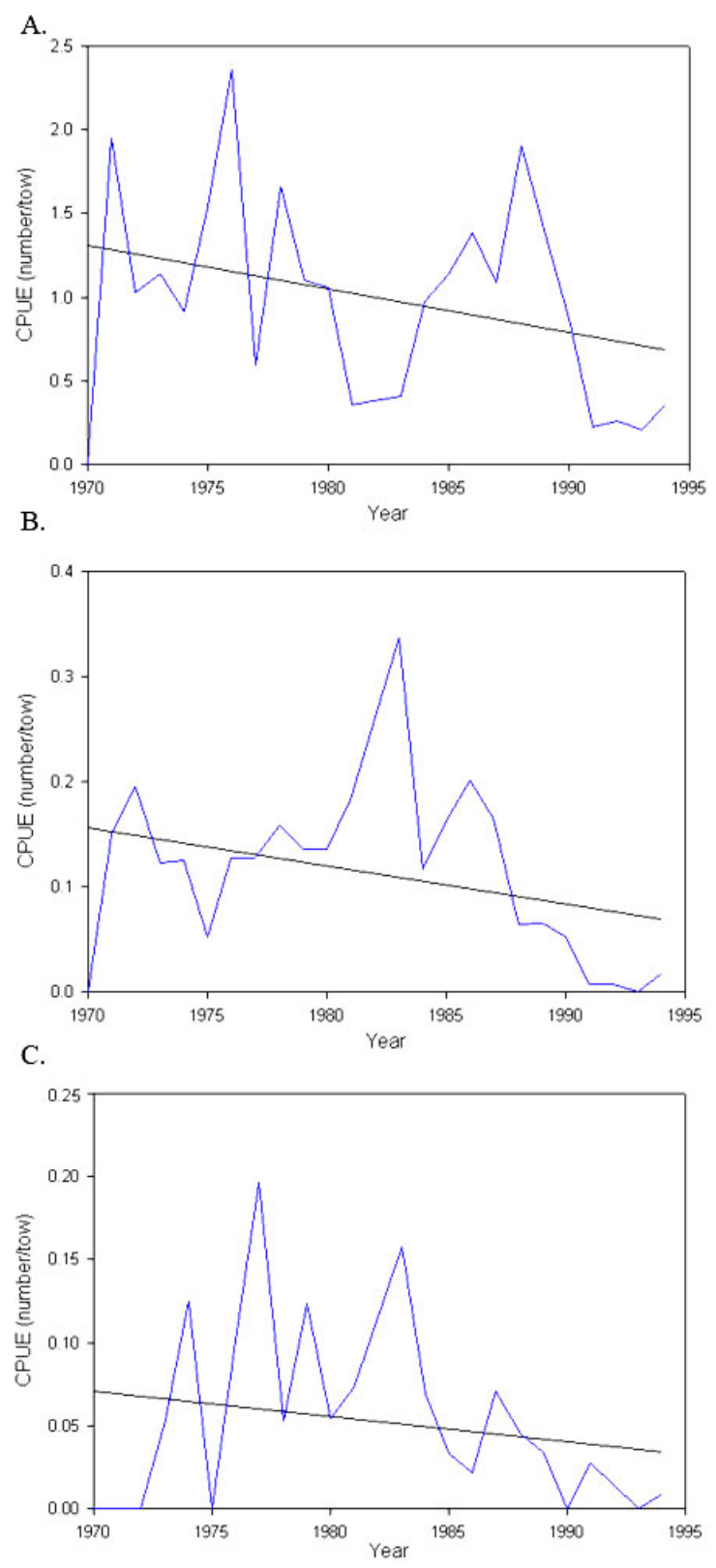

\section{ECNASAP}

ECNASAP data for all of Newfoundland and Labrador show that the peak catch rates for A. lupus, the most common species, were seven per tow from 1975-1979 in their entire range and decreased to three per tow from 1980 to 1994. Plots of the data from the northern Gulf (4R) showed negative trends in CPUE from 1970 to 1994 for all three species of wolfish (Fig. 5). 
Table 1. Trends in catch rates of Anarhichas lupus, A. minor, and A. denticlatus by area surveyed, fisheries data source, and time frame.

\begin{tabular}{|c|c|c|c|c|c|}
\hline Area & Source of Data & $\begin{array}{l}\text { Time - } \\
\text { Start }\end{array}$ & $\begin{array}{l}\text { Time - } \\
\text { Stop }\end{array}$ & Wolffish species & Trend \\
\hline Northern Gulf of St. Lawrence (4R) & ECNASAP & 1970 & 1994 & $\begin{array}{l}\text { A. lupus } \\
\text { A. minor } \\
\text { A. denticulatus }\end{array}$ & $\begin{array}{l}-2.8 \% / \mathrm{yr} \\
-0.39 \% / \mathrm{yr} \\
-0.16 \% / \mathrm{yr}\end{array}$ \\
\hline $\begin{array}{l}\text { Northern Gulf of St. Lawrence } \\
\text { (3Pn4R) }\end{array}$ & Sentinel & 1999 & 2009 & $\begin{array}{l}\text { A. lupus } \\
\text { A. minor } \\
\text { A. denticulatus }\end{array}$ & $\begin{array}{l}\text { Increase } \\
\text { (nonsignificant) } \\
\text { Data deficient }\end{array}$ \\
\hline $\begin{array}{l}\text { Waters around Newfoundland and } \\
\text { Labrador, majority on Grand Banks } \\
\text { and the eastern shelf (no NAFO } \\
\text { divisions listed) }\end{array}$ & $\begin{array}{l}\text { Species Status Reports } \\
\text { (O'Dea and Haedrich 2000, } \\
\text { O'Dea and Haedrich 2001a, } \\
\text { O'Dea and Haedrich 2001b) }\end{array}$ & 1978 & 1993 & $\begin{array}{l}\text { A. minor } \\
\text { A. denticulatus }\end{array}$ & $\begin{array}{l}97 \% \text { decline } \\
98 \% \text { decline }\end{array}$ \\
\hline $\begin{array}{l}\text { Waters around Newfoundland and } \\
\text { Labrador (majority in } 3 \mathrm{LNO} \text { ) }\end{array}$ & $\begin{array}{l}\text { Recovery Plan } \\
\text { (Kulka et al. 2007) }\end{array}$ & 1977 & 2001 & $\begin{array}{l}\text { A. lupus } \\
\text { A. minor } \\
\text { A. denticulatus }\end{array}$ & Over $90 \%$ decline \\
\hline
\end{tabular}

ECNASAP $=$ East Coast of North America Strategic Assessment Project

NAFO $=$ Northwest Atlantic Fisheries Organization

The trends in each of the three species were not statistically significant but were biologically significant for $A$. lupus $(-2.8 \% / \mathrm{yr}$ x $24 \mathrm{yr}=67 \%$ ). Analysis of covariance showed that the heterogeneity of slopes among species, while substantial, was not significant $\left(\mathrm{F}_{2,66}=1.97, \mathrm{p}=0.148\right)$ at a level that allowed a more sensitive test based on all three species. The combined trend (all species) was negative $(-1.1 \% / y r)$ but just short of statistical significance at the $5 \%$ criterion $\left(\mathrm{F}_{1,66}=3.47, \mathrm{p}=0.067\right)$. The contrast in the magnitude of trends from the northern Gulf as compared with the larger scale analysis for all waters around Newfoundland (Table 1) is notable. The larger scale analyses (Table 1) exceeded the criterion for listing a species as Special Concern or Threatened under COSEWIC, i.e., a decline of $\geq 50 \%$.

All three species of wolffish were found to some degree in shallow waters $(<200 \mathrm{~m})$ of the northern Gulf (Brown et al. 1996). In the rest of their Newfoundland range, however, they were concentrated in the deeper, offshore waters. A. lupus was found to have a distribution throughout the entire study area, with the highest catches found in $<200 \mathrm{~m}$. A. minor showed a deeper distribution $>200 \mathrm{~m}$. A . denticulatus was concentrated offshore, with only scattered catches during the time series found between $0-200 \mathrm{~m}$.

\section{Sentinel}

All three species were found in the entire study area. The majority of $A$. lupus and A. minor intercepted in the Sentinel surveys were caught in waters under $200 \mathrm{~m}$ of depth (Figs. 2 and 3). Few of either species were caught outside of $200 \mathrm{~m}$. Only $12 A$. denticulatus were intercepted over 1991-2008, and only one of these was caught in depths less than $250 \mathrm{~m}$ (Fig. 4). No trends in distribution, assessed visually by year on maps, were found for any of the three species in the Sentinel data.
Catch rates between the species differed significantly. Catches of A. lupus were the highest of the three species, ranging from 1 - 2 to 45. A. minor, although found in the same ranges, had much lower catches per tow, the highest at 7/tow. A. denticulatus had the lowest catch rates (maximum of $2 /$ tow). In mobile gear Sentinel surveys, catches of both $A$. minor and $A$. denticulatus were too low to calculate CPUE. For A. lupus CPUE (number/ tow) the trend was positive, but not statistically significant.

Length frequency was calculated from Sentinel catches 1998 to 2008. A. lupus showed a positive skew away from modal values of around $150-250 \mathrm{~mm}$. The majority of fish from 1998-2004 consisted of juveniles (less than $550 \mathrm{~mm}$ ). From 2004-2008 the distribution became bimodal, with a second peak around 500 650, showing an increase in adult $A$. lupus. From this data, the juvenile:adult ratio for $A$. lupus in $3 \mathrm{Pn}$ and $4 \mathrm{R}$ was $9.8: 1(\mathrm{n}=1942)$.

\section{DISCUSSION}

This case study of wolffish in the northern Gulf of St. Lawrence indicates that, for wolffish, an examination of harvester LEK supplemented by regional scale analyses of fishery-independent survey data can lead to a better understanding of the species and increasingly protective species at risk legislation. We show that fishery-independent survey data and data from LEK interviews can be used conjointly, given three criteria: a general concurrence of data, presence of unexplainable inconsistencies, and a degree of complementarity between LEK and science data. There was consistency in observed trends and locations of high wolffish catch rates. Inconsistency occurred in observed variability in catch amounts. Finally, results from wolffish size assessments are concurrent in that adult wolffish were found in inshore catches and juveniles in offshore catches. The LEK and science data were complementary in that observations took place at different spatial and temporal scales. 
Although wolffish are distributed throughout most Newfoundland waters, they have been historically relatively rare in number. Population sizes have never been high or consistent enough for any of the three species to sustain a commercial fishery; all wolffish landings and discards to date have been due to bycatch. The lack of a directed fishery coupled with low population numbers are among the reasons why wolffish were not heavily studied or monitored in the past. Recently there has been an increase in wolffish research in both Canada and the United States as a result of the species at risk listings. Most of the recent research has focused on their abundance, molecular biology, and their use as an aquaculture species, with less research taking place on ecology and biogeography.

Both the Sentinel survey data and the harvester interviews suggest both spatial and temporal variability in wolffish distribution along the Newfoundland coast of the northern Gulf of St. Lawrence. Both the ECNASAP and Sentinel survey data and the harvester interview data show that wolffish had a more southern distribution in areas $4 \mathrm{R}$ and $3 \mathrm{Pn}$. The reasons for this variability are unknown, but may be related to habitat selection, feeding, or spawning requirements.

Sentinel data provided a different picture from LEK interviews, which tend to be based on inshore observations. Both ECNASAP and Sentinel data show both $A$. lupus and A. minor commonly in inshore waters $(<200 \mathrm{~m})$ and $A$. denticulatus in offshore waters (>200 m). Harvesters reported A. lupus most commonly in waters $2-40 \mathrm{~m}, A$. minor in waters $40-150 \mathrm{~m}$, and A. denticulatus in the deepest waters from $100-350 \mathrm{~m}$. The ECNASAP groundfish distribution maps show that in other waters around Newfoundland, wolffish are found in much deeper, offshore waters than appears to be the case in the northern Gulf. Charts created from both Sentinel and ECNASAP data also show an absence of wolffish from Port aux Choix north through the Strait of Belle Isle, to the offshore waters of the northeastern coast.

The inconsistency in reported depths of wolffish can be explained by the influence of the Labrador Current. The Strait of Belle Isle is influenced by the Labrador Current through tides and currents. Temperatures in this area are the coldest in the northern Gulf. Although wolffish can survive in freezing temperatures because of antifreeze proteins in the blood, similar to those of the winter flounder, they are most often found in a range of $2-5^{\circ} \mathrm{C}$ (Kulka et al. 2004). Therefore, the distribution of all three species of wolffish was limited to the waters south of Port aux Choix in the Northern Gulf and to the deeper offshore waters of the Labrador and northeastern Newfoundland coast.

Wolffish sizes reported by harvesters during interviews suggest that a high ratio of adults (length of $>55 \mathrm{~cm}$ ) are caught in various gear, including lobster pots, gillnets, and longlines, in inshore fisheries. In contrast, Sentinel data in deeper waters, using trawls, showed an overwhelming trend toward juvenile wolffish. This can be explained by segregation by water depth of adults and juveniles during the summer months with juveniles remaining in deeper waters for feeding and to escape predation, while adults migrate to shallower waters. Nelson and Ross (1992) reported that with increasing depth A. lupus segregate by size. They showed that, from March to May, adult wolffish composed the largest proportion of catches in waters less than $120 \mathrm{~m}$, while the ratio of juveniles increased with depth.
This segregation can be explained by seasonal inshore-offshore movement (Nelson and Ross 1992). This migration inshore accompanies a lowering of feeding activity for mate choice and reproduction. Nonbreeding juveniles do not make the migration inshore and instead remain offshore. A. minor is assumed to follow this trend (Bigelow and Schroeder 2002), whereas A. denticulatus, rarely found in shallow waters, is assumed to remain in deeper waters. It is unknown if there is any segregation of adults and juveniles for this species.

Another explanation for the segregation of adults and juveniles during summer months comes from the Sentinel trawl offshore sampling methods. Other research vessel surveys have reported size biases due to sampling gear and methodology because they do not sample mature fish well (McRuer et al. 2000). Sentinel data may follow this trend.

The high ratio of adult wolffish reported in inshore fishery catches by harvesters would have detrimental consequences for wolffish conservation if coupled with low survival rates. However, since the listing of wolffish in 2003 under SARA, all three species of wolffish have to be released alive when caught, the exception being for $A$. lupus. Two hundred pounds per day (or $10 \%$ of the daily catch) of $A$. lupus can be kept for sale (Kulka et al. 2004). The live release of wolffish has been shown to result in a high survival rate, even days later (Grant et al. 2005). A high survival rate of released wolffish is also consistent with the reported increased sizes of wolffish being caught.

A high survival rate is also consistent with harvester reported changes in wolffish catch rates over their careers. Reported catch rates between the two survey types differed. Catch sizes reported by harvesters had generally increased over their careers, whereas Sentinel data and species survey reports did not show this increase. This may be due to the extended time frame of the harvester reports, sampling depths, or gear of the trawls.

Catch per unit effort is known to be a poor indicator of abundance for schooling fish, compared with the use of CPUE to track change in abundance of nonschooling bottom fish such as wolffish. The substantial decline in catch per unit effort at the larger scale of waters around Newfoundland stands in contrast to declines seen in the Gulf of St. Lawrence (Table 1). In the Gulf, the changes in catch per unit effort from the Sentinel fishery were not inconsistent with those from LEK. The results from LEK (all species) differed from the results (all species) from the ECNASAP data. Of note is that the research vessel catch rates in 4RST have shown an increase in wolffish numbers, which has been attributed to higher recruitment (McRuer et al. 2000).

Efforts at combining LEK and science-based CPUE to estimate trends in abundance is especially fraught because efficiency (maximize CPUE) drives the former, whereas consistency via fixed effort is the goal of the latter. Decadal scale trends in harvester reported catch rates for wolfish may be due to changes, in recent years, in season length, depth, and areas fished in groundfish fisheries, in particular. For wolffish, there may be a bias in reported numbers associated with these changes since the species were listed, or there may be bias because harvesters are now paying more attention to the species because they have to be released alive. 


\section{CONCLUSIONS}

Social and economic considerations are to an increasing degree considered in species at risk discussions in Canada, but at present the current system struggles with including LEK, as well as traditional assessments in SARA processes. LEK provides a wider range of information; for example, a wider range in seasonal information than a scientific survey. However, although LEK can be gathered and assembled, it does not lend itself to inclusion in a science-based and quantitative setting via numerical weighting. We show that qualitative criteria can be used to tap into the often wider range of information from LEK. The spatial and temporal scales of LEK and science data differ, but, to the degree that LEK findings are internally consistent, LEK and science information can be used to judge external consistency of these two different forms of information.

The reported lack of decline in wolffish catch rates and range among interviewed harvesters in areas with traditionally high populations agrees with trends generated from ECNASAP survey data, but not data from areas of historically higher wolffish abundance around Newfoundland, such as the Grand Banks and the northeastern shelf. Areas with traditionally low populations of wolffish did not have high enough catches of wolffish in the past for a good comparison of trends to be possible. In the northern Gulf of St. Lawrence, this lack of observed decline has led to questions about legislation. Legislation is often perceived by harvesters as political in motivation, while simultaneously offering little help to harvesters. National legislation, necessary at a large scale, can also lead to a local disconnect when the science on which it is based does not seem to match local observations. Discrepancies between science and LEK such as this are often due to the differences in scales (small scale of inshore harvesters versus the larger scale of fisheries assessments). These differences can lead local harvesters to ignore regulations, and to mistrust the science basis for regulation at spatial scales greater than their own experience. The inclusion of harvester LEK, through consultations and meetings with an increasingly transparent scientific process, will help the species at risk legislation by eliminating some of the discrepancies between science and harvester knowledge that trouble harvesters. Consilience of LEK and science evidence will strengthen knowledge of those species that are identified as at risk by science-based numerical criteria of substantial decline in numbers.

Responses to this article can be read online at: http://www.ecologyandsociety.org/issues/responses. $\mathrm{php} / 6674$

\section{Acknowledgments:}

This research was supported by the Social Sciences and Humanities Research Council, Memorial University, and the Research and Development Corporation of Newfoundland and Labrador, with additional financial and in-kind support from numerous community partners and groups. The authors would also like to thank the fish harvesters who participated in interviews and Melanie Quinlan, a student intern.

\section{LITERATURE CITED}

Berkes, F., J. Colding, and C. Folke. 2000. Rediscovery of traditional ecological knowledge as adaptive management. Ecological Applications 10:1251-1262. http://dx.doi.org/10.1890/1051-0761 (2000)010[1251:ROTEKA]2.0.CO:2

Bigelow, H. B., and W. C. Schroeder. 2002. Fishes of the Gulf of Maine. Smithsonian Press, Washington, D.C., USA.

Bourdages, J. L., and C. Labelle. 2003. Protecting wild species at risk in Canada. Government of Canada, Ottawa, Ontario, Canada.

Brown, S. K., R. Mahon, K. C. T. Zwanenburg, K. R. Buja, L. W. Claflin, R. N. O'Boyle, B. Atkinson, M. Sinclair, G. Howell, and M. E. Monaco. 1996. East coast of North America groundfish: initial explorations of biogeography and species assemblages. Marine Fish Division, Department of Fisheries and Oceans, Dartmouth, Nova Scotia, Canada.

Butler, J. R. A., A. Tawake, T. Skewes, L. Tawake, and V. McGrath. 2012. Integrating traditional ecological knowledge and fisheries management in the Torres Strait, Australia: the catalytic role of turtles and dugong as cultural keystone species. Ecology and Society 17(4): 34. http://dx.doi.org/10.5751/ES-05165-170434

Dawe, J. 2010. Marine fish, local ecological knowledge, and the species at risk act in Canada: lessons from the case study of three species of wolffish. Thesis. Memorial University of Newfoundland, St. John's, Newfoundland and Labrador, Canada.

Dawe, J. L., and B. Neis. 2012. Species at risk in Canada: lessons learned from the listing of three species of wolffish. Marine Policy 36(2):405-413. http://dx.doi.org/10.1016/j.marpol.2011.06.010

Dulvy, N. K., S. Jennings, N. B. Goodwin, A. Grant, and J. D. Reynolds. 2005. Comparison of threat and exploitation status in North-East Atlantic marine populations. Journal of Applied Ecology 42:883-891. http://dx.doi.org/10.1111/j.1365-2664.2005.01063. $\underline{\mathrm{X}}$

Espinoza-Tenorio, A., M. Wolff, I. Espejel, and G. MontañoMoctezuma. 2013. Using traditional ecological knowledge to improve holistic fisheries management: transdisciplinary modeling of a lagoon ecosystem of southern Mexico. Ecology and Society 18(2): 6. http://dx.doi.org/10.5751/ES-05369-180206

Fréchet, A., J. Gauthier, and P. Schwab. 2009. Preliminary report on the July 2008 mobile sentinel survey in the Northern Gulf of St. Lawrence. Groundfish Sentinel Fisheries Program 11:10.

Grant, S. M., W. Hiscock, and P. Brett. 2005. Mitigation of capture and survival of wolffish captured incidentally in the Grand Bank yellowtail flounder otter trawl fishery. Centre for Sustainable Aquatic Resources, Marine Institute of Memorial University of Newfoundland, St. John's, Newfoundland and Labrador, Canada.

Kulka, D. W., C. Hood, and J. Huntington. 2007. Recovery strategy for northern wolffish (Anarhichas denticulatus) and spotted wolffish (Anarhichas minor) and management plan for Atlantic wolffish (Anarhichas lupus) in Canada. Fisheries and Oceans Canada, Newfoundland and Labrador Region, St. John's, Newfoundland and Labrador, Canada. 
Kulka, D. W., M. R. Simpson, and R. G. Hooper. 2004. Changes in distribution and habitat associations of wolffish (Anarhichidae) in the Grand Banks and Labrador Shelf. Pages 1-48 in Canadian Science Advisory Secretariat Research Document. Fisheries and Ocean Canada, Government of Canada, Ottawa, Ontario, Canada.

McRuer, J., T. Hurlbut, and B. Morin. 2000. Status of Atlantic wolffish (Anarhichas lupus) in the Maritimes (NAFO Sub-Area 4 and 5). Pages 1-55 in Canadian Stock Assessment Secretariat Research Document. Fisheries and Ocean Canada, Government of Canada, Ottawa, Ontario, Canada.

Murray, G., B. Neis, D. C. Schneider, D. Ings, K. Gosse, J. Whalen, and C. T. Palmer. 2008. Opening the black box: methods, procedures, and challenges in the historical reconstruction of marine social-ecological systems. Pages 100-120 in J. Lutz and B. Neis, editors. Making and moving knowledge: interdisciplinary and community-based research for a world on the edge. McGill-Queen's University Press, Montréal, Québec, Canada.

Musick, J. A. 1999. Criteria to define extinction risk in marine fishes: the American Fisheries Society initiative. Fisheries 24:6-14. http://dx.doi.org/10.1577/1548-8446(1999)024<0006:CTDERI> 2.0. $\mathrm{CO} ; 2$

Neis, B., L. Felt, R. L. Haedrich, and D. C. Schneider. 1999a. An interdisciplinary method for collecting and integrating fishers' ecological knowledge into resource management. Pages 217-238 in D. Newell and R. Ommer, editors. Fishing places, fishing people: traditions and issues in Canadian small-scale fisheries. University of Toronto Press, Toronto, Ontario, Canada.

Neis, B., D. C. Schneider, L. Felt, R. L. Haedrich, J. Fischer, and J. A. Hutchings. 1999b. Fisheries assessment: what can be learned from interviewing resource users? Canadian Journal of Fisheries and Aquatic Sciences 56:1949-1963. http://dx.doi.org/10.1139/ $\underline{\text { f99-115 }}$

Nelson, G. A., and M. R. Ross. 1992. Distribution, growth and food habits of the Atlantic Wolffish (Anarhichas lupus) from the Gulf of Maine-Georges Bank Region. Journal of Northwest Atlantic Fisheries Sciences 13:53-61. http://dx.doi.org/10.2960/J. $\underline{\mathrm{v} 13 . \mathrm{a} 4}$

O'Dea, N., and R. L. Haedrich. 2000. COSEWIC status report on the spotted wolffish Anarhichas lupus in Canada. Committee on the Status of Endangered Wildlife in Canada, Ottawa, Ontario, Canada.

O'Dea, N., and R. L. Haedrich. 2001a. COSEWIC status report on the spotted wolffish Anarhichas denticulatus in Canada. Committee on the Status of Endangered Wildlife in Canada, Ottawa, Ontario, Canada.

O'Dea, N., and R. L. Haedrich. 2001b. COSEWIC status report on the spotted wolffish Anarhichas minor in Canada. Committee on the Status of Endangered Wildlife in Canada, Ottawa, Ontario, Canada.

Sáenz-Arroyo, A., C. M. Roberts, J. Torre, and M. Cariño-Olvera. 2005. Using fishers' anecdotes, naturalists' observations and grey literature to reassess marine species at risk: the case of the Gulf grouper in the Gulf of California, Mexico. Fish and Fisheries 6:121-133. http://dx.doi.org/10.1111/j.1467-2979.2005.00185.x
Thornton, T. F., and A. Maciejewski Scheer. 2012. Collaborative engagement of local and traditional knowledge and science in marine environments: a review. Ecology and Society 17(3): 8. http://dx.doi.org/10.5751/ES-04714-170308

Usher, P. J. 2000. Traditional ecological knowledge in environmental assessment and management. Arctic 53:183-193. http://dx.doi.org/10.14430/arctic849

Van Holt, T. 2012. Landscape influences on fisher success: adaptation strategies in closed and open access fisheries in southern Chile. Ecology and Society 17(1): 28. http://dx.doi. org/10.5751/ES-04608-170128

Vodden, K., R. Ommer, and D. C. Schneider. 2005. A comparative analysis of three modes of collaborative learning in fisheries governance: hierarchy, networks and community. Pages 291-306 in T. S. Gray, editor. Participation in fisheries governance. Springer, Dordrecht, The Netherlands. http://dx.doi.org/10.1007/1-4020-3778-3 17

Whewell, W. 1840. The philosophy of the inductive sciences, founded upon their history. John W. Parker, London, UK. [online] URL: http://archive.org/details/philosinductsci01wewrich 